\title{
HUBUNGAN DIMENSI MEJA MAKAN TERHADAP TERITORI PERSONAL PADA RESTORAN DENGAN PENGATURAN MAKAN A LA CARTE
}

\author{
Erlana Adli Wismoyo ${ }^{(1)}$, Rizka Suci Utami(2) \\ Program Studi Desain Interior, Fakultas Industri Kreatif, Telkom University \\ erlanadliw@telkomuniversity.ac.id, rizkasuciutami@student.telkomuniversity.ac.id
}

\begin{abstract}
Abstrak
Saat ini beragam jenis restoran menjadi tempat tujuan untuk menikmati berbagai macam hidangan, pada restoran tentu saja terdapat beberapa area. Area makan pengunjung merupakan salah satu area yang sangat penting karena pada area tersebut pengunjung akan merasakan bagaimana aktivitas makan dan minum pada suatu restoran. Pada saat hidangan di letakan di atas meja dan pengunjung melakukan aktivitas makan dan minum maka akan berpengaruh pada dimensi furniture yang digunakan. Setiap restoran menerapkan sistem makan yang berbeda salah satunya adalah sistem makan a la carte. Sistem makan ini tentunya berpengaruh terhadap dimensi furniture pada suatu restoran yang berhubungan dengan aktivitas di restoran dan teritori personal yang dirasakan oleh pengunjung. Tujuan dari penelitian ini adalah untuk mengetahui hubungan dimensi meja makan dengan teritori personal pada braga permai pengaturan makan a la carte. Analisa data di dapatkan dengan cara mengumpulkan data dan dengan survey langsung pada restoran braga permai yang menerapkan sistem makan a la carte kemudian data tersebut diolah secara deskriptif. Hasil dari penelitian ini untuk merekomendasikan dimensi pengaturan meja makan yang sesuai dengan teritori pengguna terhadap furniture dan hidangan yang disajikan.
\end{abstract}

Kata kunci: Teritori, Dimensi Furnitur, Restoran.

\begin{abstract}
Nowadays, various types of restaurants are becoming the destination to enjoy various kinds of dishes, of course there are several areas in the restaurant. The dining area for visitors is one of the most important areas because in that area, visitors will feel the eating and drinking activities in a restaurant. When the dish is placed on the table and visitors eat and drink, it will affect the dimensions of the furniture used. Each restaurant applies a different dining system, one of which is the a la carte dining system. This dining system certainly affects the dimensions of furniture in a restaurant that is related to the activities in the restaurant and the personal territory that visitors perceive. The purpose of this study was to determine the relationship between the dimensions of the dining table and the personal territory of the Braga Permai with a la carte dining arrangements. Data analysis is obtained by collecting data and by conducting direct surveys at Braga Indah restaurant that apply the a la carte dining system then the data is processed descriptively. The results of this study are to recommend the dimensions of the dining table setting according to the user's territory of the furniture and dishes served.
\end{abstract}

Keywords: Territory, Furniture Deimensions, Restaurant. 


\section{Pendahuluan}

Saat ini beragam jenis restoran menjadi tempat tujuan untuk menikmati berbagai macam hidangan. Setiap restoran tentu saja memilki ciri khas masing-masing yaitu berupa dekorasi, sistem makan, bentuk furniture dan lain-lain. Sistem makan atau cara makan dan bentuk furniture menyesuaikan dengan konsep restoran. Pada restoran yang menerapkan pengaturan makan seperti pada restoran Eropa biasanya menggunakan sistem makan a la carte. Perancis adalah salah satu negara di Eropa yang terkenal akan kulinernya yang banyak menggunakan sistem makan a la carte. Peralatan makan yang digunakan oleh restoran Perancis banyak ditiru dan digunakan oleh negara lain, Perancis memiliki budaya kuliner dengan etika dan pengaturan meja makan yang masih digunakan hingga saat ini. Ada 2 hal yang menjadi ciri khas dalam kuliner Perancis yaitu bahan olahan dan cara penyajiannya. Urutan penyajian hidangan Perancis yaitu hidangan yang pertama disajikan adalah hidangan pembuka (appetizer/hors d'oeuvre) berupa sup, daging asap atau salad. Kedua adalah hidangan utama, hidangan berbahan daging atau ikan, sayur dan nasi atau pasta. Ketiga yaitu hidangan penutup (dessert).

Furniture yang digunakan yaitu meja dan kursi makan harus memiliki ukuran yang standar dan sesuai dengan ergonomi agar aktifitas makan minum maupun aktifitas lainnya dapat dilakukan dengan baik. Untuk itu dimensi pada furniture yang digunakan harus sesuai dengan dimensi standar furniture. Pada saat pengunjung datang ke sebuah restoran kemudian duduk dan menyantap hidangan yang berada diatas meja tentu saja pengunjung memiliki hak teritori pada meja dan kursi tersebut. Teritori manusia dapat dilihat dalam segala ruang kegiatan baik publik maupun ruang privat. Salah satunya adalah restoran yang memiliki nilai teritori manusia yang mampu memberikan kenyamanan terhadap pengunjung restoran. Perilaku teritorial ini ditampilkan setiap hari di pengaturan layanan, termasuk kafe, toko buku, pusat kebugaran, dan bahkan lounge kapal pesiar, lobi, dan kolam renang (Griffiths: 2012). Perilaku teritori dalam sebuah restoran dapat dilihat langsung dengan pengelompokan antar pengujung yang tidak bersinggungan langsung dengan pengunjung lainnya. Menurut Brown dan Bentley: 1993 (dalam Griffiths :2012) perilaku teritorial dirancang untuk menjaga orang lain agar tidak mengganggu batas orang lain dan mencegah pelanggaran, membatasi batas-batas semu, sementara lainlain dirancang untuk menandakan kepemilikan dan hunian, dan mengidentifikasi identitas seseorang. Buku Human Dimension menjadi sumber acuan untuk menentukan dimensi meja makan yang sesuai agar aktifitas makan minum maupun aktifitas lainnya dapat dilakukan dengan nyaman. Teritori personal setiap pengunjung pada restoran menyesuaikan dengan kapasitas meja makan yang digunakan , apabila meja makan yang digunakan kapasitasnya untuk 4 orang pengunjung maka teritrori personal tersebut dibagi menjadi seperempat, namun tentu saja dalam hal ini dimensi meja yang digunakan harus sesuai tidak boleh kurang, karena jika kurang pengunjung akan merasa tidak nyaman dalam menyantap hidangan. Hak teritori personal tersebut tidak hanya digunakan untuk aktivitas makan dan minum saja namun juga ada aktivitas lain yaitu, menggunakan ponsel, meletakkan aksesori atau tas dan aktivitas pengunjung lainnya, jadi dimensi meja makan untuk teritori personal tersebut juga perlu di perhatikan. Penelitian ini menganalisis salah satu restoran populer di Bandung yaitu restoran Braga Permai dengan melakukan simulasi pengaturan makan untuk mengetahui teritori personal pengunjung pada meja makan. Penelitian ini bertujuan untuk mengetahui hubungan dimensi meja makan dengan teritori personal pada restoran Braga Permai yang menggunakan pengaturan makan a la carte.

\section{Metode}

Metode penelitian yang digunakan adalah metode penelitian kualitatif, yaitu analisa data di dapatkan dengan cara mengumpulkan data dan dengan survey langsung pada restoran Braga Permai yang menerapkan sistem makan a la carte kemudian data tersebut diolah secara deskriptif. Hasil dari penelitian ini untuk merekomendasikan dimensi pengaturan meja makan yang sesuai dengan teritori pengguna terhadap furniture dan hidangan yang disajikan. Penelitian tersebut berkaitan dengan aktivitas makan dan minum pengunjung yang berhubungan dengan teritori personal meja makan untuk pengaturan makan a la carte. 


\section{Pembahasan}

\section{Restoran Eropa (Prancis)}

Perancis adalah salah satu negara yang terkenal dengan kulinernya, juga termasuk negara yang elegan dengan gaya memasaknya dan sangat konvensional karena metode memasaknya, gaya memasaknya, dan peralatan yang digunakan oleh orang-orang Perancis banyak ditiru dan digunakan oleh negara lainnya. Di restoran Prancis, penyajian hidangan dan posisi alat makan selalu diatur sedemikian rupa agar tetap rapi dan teratur saat digunakan termasuk posisi sendok, garpu, dan pisau yang menjadi salah satu alat bantu utama untuk menyantap makanan. Oleh karena itu kuliner di negara ini mempunyai nilai seni yang tinggi dan menjadikan negara ini mempunyai banyak makanan yang menjadi ciri khas. Nilai seni dalam memasak ala Perancis menjadikan beberapa negara di dunia banyak yang meniru gaya dan metode memasak ala Perancis. Ada 2 hal yang menjadi ciri khas dalam kuliner Perancis yaitu bahan olahan dan cara penyajiannya. Urutan penyajian hidangan Perancis yaitu hidangan yang pertama disajikan adalah hidangan pembuka (appetizer/hors d'oeuvre) berupa sup, daging asap atau salad. Kedua adalah hidangan utama, hidangan berbahan daging atau ikan, sayur dan nasi atau pasta. Ketiga yaitu hidangan penutup (dessert).

\section{Pelayanan Restoran Prancis}

Di restoran Prancis, penyajian hidangan dan posisi alat makan selalu diatur sedemikian rupa agar tetap rapi dan teratur saat digunakan termasuk posisi sendok, garpu, dan pisau yang menjadi salah satu alat bantu utama untuk menyantap makanan. Pelayanan pada restoran Perancis sering di kenal dengan istilah French service. French service merupakan service yang paling mahal, yang biasanya terdapat di restoran formal dining room atau grill room. Semua jenis hidangan disiapkan (dimasak dan dihias) dan disajikan secara demonstrative di depan pelanggannya oleh dua orang pramusaji dan beberapa petugas khusus yang melayani minuman. Meskipun masing-masing mempunyai tugas sendiri-sendiri, mereka ini merupakan tim yang saling membantu satu sam lain. Mereka biasanya terdiri dari pramusaji senior yang disebut chef de rang yang dibantu oleh pramusaji junior yang disebut commis de rang dan pramusaji khusus yang melayani minuman wine yang disebut sommelier. Pekerjaan memasak, mengatur dan menyajikan makanan dilakukan dihadapan tamu/pemesan hidangan, dengan menggunakan kereta dorong berdesain, lengkap dengan peralatan-peralatan seperti kompor, tempat tabung gas, bumbu-bumbu, tempat memotong, dan tempat menaruh piring panas. Kereta dorong ini dirancang dan dikemas dalampenataan yang praktis agar dapat memenuhi kebutuhan operasional sehingga bisa berfungsi sebagai dapur, dengan ketinggian yang sama dengan meja makan. Uniknya, kereta ini dapatdengan mudah dipindahkan dari satu sisi meja ke sisi meja yang lainnya dengan hanyamendorongnya saja. Kereta ini biasanya disebut dengan gueridon. Oleh karena itu Frenchservice dikenal juga dengan gueridon service.

Langkah-langkah French service:

1. Chef de rang menyerahkan kertas order kepada commis de rang.

2. Commis de rang menyerahkan lembaran order ke juru masak di dapur agar bahan-bahan untuk suatu hidangan disiapkan.

3. Bahan makanan yang masih mentah atau setengah jadi disiapkan sesuai pesananyang tertulis di kertas order, kemudian dibawa oleh commis de rang dandiserahkan kepada chef de rang.

4. Chef de rang memasak, mengatur piring panas, memberi garnish (hiasan), dan menata hidangan sampai siap dihidangkan.

5. Setelah segala sesuatu diatur di piring panas sudah terlihat rapi, segera dihidangkan oleh commis de rang kepada tamu. Posisi pada waktu menghidangkan makanan dari sebelah kanan tamu dengan tangan kanan, sementara kaki kanansetengah langkah ke depan. 
6. Clear-up bekas piring makan serta peralatan makan dilakukan dengan cara diambildari sebelah kanan tamu, kecuali bread \& butter plate, finger bowl, dan salad bowl, yang diambil dari sebelah kiri dengan tangan kiri.

7. Service semua minuman dilakukan dari sebelah kanan tamu dengan tangan kanan. Tangan kiri membawa nampan berisi gelas minuman, tangan kanan menyajikan/memindahkan minuman dari nampan ke meja tamu.

8. Clear-up semua gelas dilakukan dari sebelah kanan tamu dengan tangan kanan, sementara tangan kiri membawa baki kecil, kemudian gelas kotor diambil dengantanan kanan, lalu diletakkan di baki yang dibawa dengan tangan kiri.

9. Hidangan yang biasanya dihidangan dengan system French service antara lain: Chateau Briand, Lobster Thermidor, Crepes Suzette, Cherry Jubely.

10. Beberapa variasi dari French service ini misalnya: salad cart, pastry wagon, hors d'oeuvre trolley, dessert cart, dll.

\section{Teritorialitas}

Hall (1969) menyatakan bahwa teritorialitas berhubungan dengan privasi yang berhubungan dengan kepemilikan dan tingkat kontrol bahwa penghuni memiliki kuasa atas penggunaan suatu tempat. Brower (1976) juga menjelaskan bahwa teritorialitas merupakan hubungan individu atau kelompok dengan seting fisiknya, yang dicirikan oleh rasa memiliki dan upaya kontrol terhadap penggunaan interaksi yang tidak diinginkan melalui kegiatan penempatan, mekanisme defensif dan keterikatan. Kontrol teritorial memungkinkan untuk mencapai tingkat privasi dan keintiman yang berbeda dari tingkat tinggi hingga tingkat rendah. Stea (1965) \& Holahan (1982) dalam Angkasa (1998) menyatakan bahwa teritorialitas merupakan suatu pola tingkah laku yang berhubungan dengan rasa kepemilikan atau hak seseorang atau sekelompok orang pada suatu tempat atau suatu lokasi geografis. Sedangkan menurut Lauren (2005), teritorialitas sebagai suatu pola tingkah laku yang merupakan perwujudan egoisme sebagai perwujudan privasi. Secara geografis, teritorialitas adalah bentuk perilaku spasial (Sack, 1986 dalam Raffestin, 2012). Teritorialitas merupakan aspek khusus perilaku spasial yang pertama kali digunakan dalam hubungan perilaku spasial hewan (Brower, 1976). Perilaku teritorial mempersempit ruang untuk menciptakan lingkungan yang dapat diprediksi dengan rasa dan keamanan yang dialaminya.

\section{Aktivitas Pada Meja Makan Restoran}

Menurut Tjokroamudjojo (1995 : 2010) Aktivitas adalah usaha-usaha yang dikemukakan untuk melaksanakan semua rencana dan kebijaksanaan yang telah dirumuskan dan ditetapkan untuk melengkapi segala kebutuhan alat-alat yang diperlukan, siapa yang akan melaksanakan, ditempat mana pelaksanaannya, kapan waktu dimulai dan berakhir, dan bagaimana cara yang harus dilaksanakan. Ukuran atau dimensi pada suatu restoran harus cukup baik dalam memfasilitasi penggunanya yaitu fasilitas untuk area perlengkapan makan minum, nomor meja, tissue, dan bumbu-bumbu (pelengkap makanan) pada setiap meja jika ada, serta perlengkapan pengunjung seperti handphone, tas, dan lainnya. Menu yang dihidangkan kebanyakan adalah menu khusus untuk 1 orang saja, sehingga dibutuhkan area personal yang cukup. Area personal tersebut memungkinkan pengunjung untuk bergerak dan melakukan aktivitas dengan nyaman. 


\section{Dimensi Standar Meja Makan Restoran}

- 6 Seater

Teritori personal yang standar menurut buku human dimension ketika makan bersama (6 seater) adalah $80-121,9 \mathrm{~cm}$, teritori atau area dengan ukuran tersebut cukup memungkinkan pengunjung bergerak dengan nyaman saat melakukan aktivitas makan dan minum maupun aktifitas lainnya.
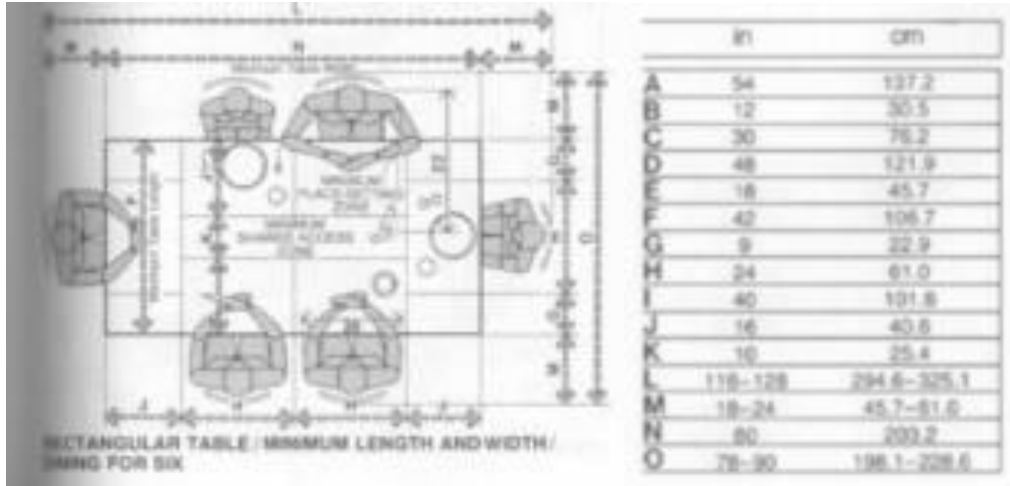

Gambar 1 Standar Dimensi Meja Makan 6 Seater

(Sumber: Neufert, 2002)

- 4 Seater

Teritori personal yang standar menurut buku Human Dimension ketika makan bersama (4 seater) adalah $60-76 \mathrm{~cm}$, sedangkan menurut buku Data Arsitek adalah sekitar $60 \mathrm{~cm}$ teritori atau area dengan ukuran tersebut cukup memungkinkan pengunjung bergerak dengan nyaman saat melakukan aktivitas makan dan minum maupun aktifitas lainnya.

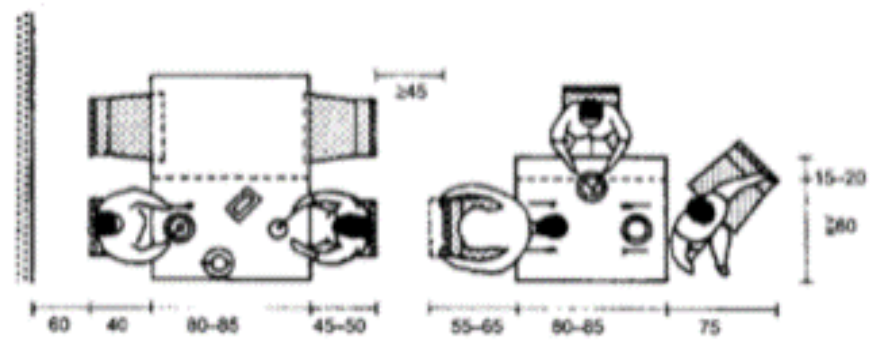

Gambar 2 Standar Dimensi Meja Makan 4 Seater (Sumber: Neufert, 2002)

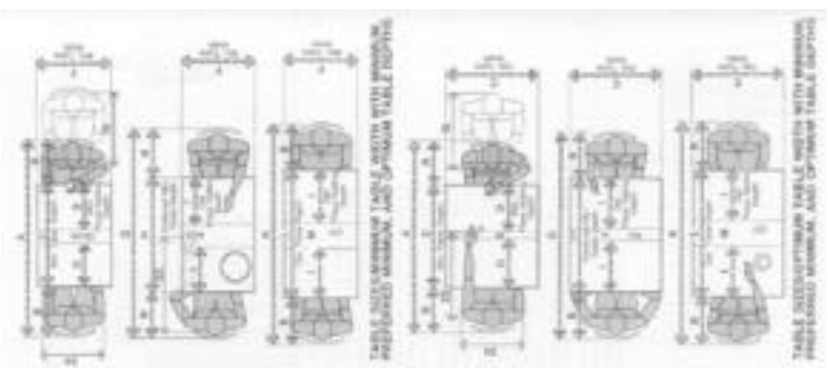

Gambar 3 Standar Dimensi Meja Makan 4 Seater (Sumber: Neufert , 2002) 


\section{Pembahasan Restroan Braga Permai}

Restoran Braga Permai terletak di jalan Braga No. 58, Braga, Kota Bandung. Restoran ini memiliki nuansa klasik dalam bangunannya. Restoran ini menempati sebuah bangunan tua peninggalan zaman belanda. Menu pada restoran Braga Permai juga diambil dari menu makanan western terutama menu khas Belanda. Restoran Braga Permai memiliki berbagai ukuran meja makan baik di smoking area maupun di non-smoking area. Braga permai menggunakan table setting yang biasanya digunakan pada restoran western lainnya. Terdapat juga beberapa pilihan kursi makan, mulai dari 4 seater, sampai sekitar 8 seater namun apabila pengunjung lebih dari 8 orang maka meja makan dan kursi makan tersebut bisa digabungkan.

\section{- Meja Makan}

Survey langsung pada restoran braga permai dilakukan oleh peneliti dengan memesan hidangan appetizer, main course, dessert, dan minuman yaitu menu a la carte atau menu untuk satu orang. Hidangan disajikan dengan bergantian yaitu menu pertama yang disajikan adalah welcome bread, menu kedua adalah menu dessert pelayan juga sembari mengambil piring dan alat makan di meja bagian pemesan yang memesan dessert kemudian menu terakhir yang disajikan adalah menu appetizer, main course, dan minuman dengan tambahan satu menu dessert.

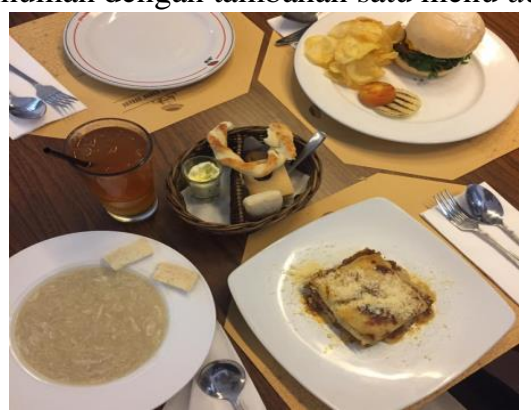

Gambar 4 Meja Makan Restoran Braga Permai (Sumber: Wismoyo, 2020)

- $\quad$ Table Setting

Table setting atau tata hidang yang digunakan pada restoran Braga Permai adalah American service. American service adalah salah satu bentuk pelayananyang dimana makanan sudah diporsikan atau disiapkan diatas piring.

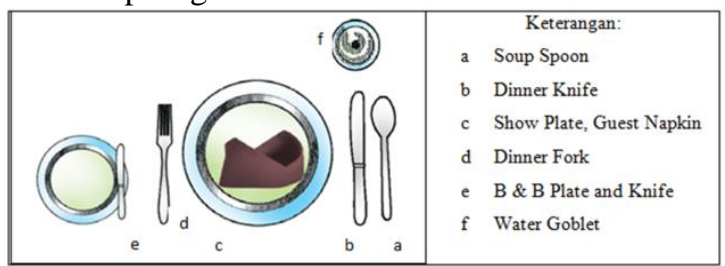

Gambar 5 Standar Table Setting

(Sumber: Food \& Beverage Table Setting)

Pada restoran Braga Permai gaya penyajian makanannya menyesuaikan konsep penyajian makanan western (belanda) yaitu dengan sistem menu persatu orang. Standar table yang digunakan pada restoran braga permai terdiri dari satu sendok, satu garpu, satu piring, satu gelas, paper untuk meletakkan alat makan tersebut, tisu, bumbu untuk penambah cita rasa hidangan (kecap, saus, dan merica), dan nomor pada setiap meja. 


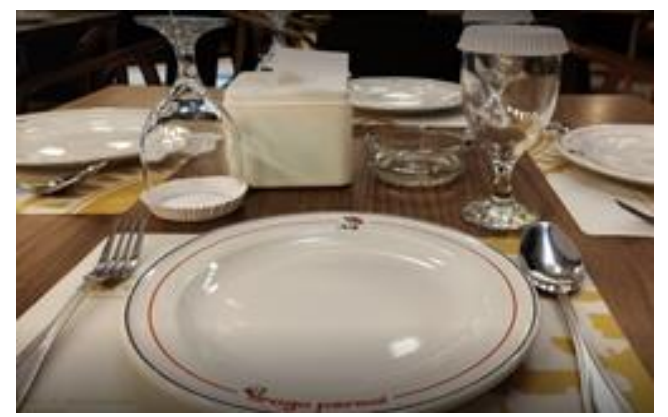

Gambar 6 Table Setting Restoran Braga Permai

(Sumber: Wismoyo 2020)

- Menu Hidangan A La Carte

Tabel berikut ini adalah tabel menu hidangan A La Carte pada restoran braga permai. tabel ini digunakan untuk menganalisa teritori personal meja makan pada saat pengunjung menyantap hidangan pada restoran braga permai.

Tabel 1 Menu Hidangan A La Carte pada Restoran Braga Permai

(Sumber: Olahan Data Peneliti 2020)

\begin{tabular}{|c|c|c|c|c|c|}
\hline No. & Restoran & $\begin{array}{l}\text { Nama } \\
\text { Menu }\end{array}$ & Dimensi & Dokumentasi & Analisa \\
\hline 1. & \multirow{3}{*}{$\begin{array}{l}\text { Braga } \\
\text { Permai }\end{array}$} & $\begin{array}{c}\text { Crab } \\
\text { assparagus }\end{array}$ & D: $22 \mathrm{~cm}$ & & $\begin{array}{l}\text { Makanan dihidangkan dengan } \\
\text { menggunakan satu piring saja dengan } \\
\text { piring yang berbentuk lingkaran yang } \\
\text { isinya berupa hidangan sup asparagus } \\
\text { yang dilengkapi roti kering atau roti khas } \\
\text { belanda. Area yang digunakan untuk } \\
\text { peletakkan piring tidak besar atau tidak } \\
\text { memakan banyak tempat sehingga } \\
\text { pengunjung bisa bergerak atau makan } \\
\text { dengan nyaman. }\end{array}$ \\
\hline 2. & & Lasagna & $\begin{array}{c}\mathrm{L} \times \mathrm{W}: 20 \mathrm{~cm} \times \\
20 \mathrm{~cm}\end{array}$ & & $\begin{array}{l}\text { Makanan dihidangkan dengan } \\
\text { menggunakan satu piring saja dengan } \\
\text { piring yang berbentuk persegi yang isinya } \\
\text { berupa hidangan lasagna. Area yang } \\
\text { digunakan untuk peletakkan piring tidak } \\
\text { besar atau tidak memakan banyak tempat } \\
\text { sehingga pengunjung bisa bergerak atau } \\
\text { makan dengan nyaman. }\end{array}$ \\
\hline 3. & & $\begin{array}{l}\text { Choco lava } \\
\text { ice cream }\end{array}$ & $\begin{array}{c}\mathrm{L} \times \mathrm{W}: 20 \mathrm{~cm} \mathrm{x} \\
10 \mathrm{~cm}\end{array}$ & & $\begin{array}{l}\text { Makanan dihidangkan dengan } \\
\text { menggunakan satu piring saja dengan } \\
\text { piring yang berbentuk persegi panjang } \\
\text { yang isinya berupa hidangan dessert yaitu } \\
\text { choco lava ice cream. Area yang } \\
\text { digunakan untuk peletakkan piring tidak } \\
\text { besar atau tidak memakan banyak tempat } \\
\text { sehingga pengunjung bisa bergerak atau }\end{array}$ \\
\hline
\end{tabular}




\begin{tabular}{|c|c|c|c|}
\hline & & & makan dengan nyaman. \\
\hline 4. & $\begin{array}{l}\text { Brownies } \\
\text { Ice cream }\end{array}$ & $\begin{array}{c}\mathrm{x} \times \mathrm{W}: 20 \mathrm{~cm} \mathrm{x} \\
10 \mathrm{~cm}\end{array}$ & $\begin{array}{l}\text { Makanan dihidangkan dengan } \\
\text { menggunakan satu piring saja dengan } \\
\text { piring yang berbentuk lingkaran yang } \\
\text { isinya berupa hidangan dessert brownies } \\
\text { Ice cream. Area yang digunakan untuk } \\
\text { peletakkan piring tidak besar atau tidak } \\
\text { memuat banyak tempat sehingga } \\
\text { pengunjung bisa bergerak atau makan } \\
\text { dengan nyaman. }\end{array}$ \\
\hline 5. & $\begin{array}{l}\text { Cheese } \\
\text { Burger }\end{array}$ & D: $28 \mathrm{~cm}$ & $\begin{array}{l}\text { Makanan di hidangkan dengan } \\
\text { menggunakan satu piring saja dengan } \\
\text { piring yang berbentuk lingkaran yang } \\
\text { isinya berupa hidangan cheeseburger. } \\
\text { Area yang digunakan untuk peletakkan } \\
\text { piring tidak besar atau tidak memakan } \\
\text { banyak tempat sehingga pengunjung bisa } \\
\text { bergerak atau makan dengan nyaman. }\end{array}$ \\
\hline 6. & $\begin{array}{l}\text { Corn Ice } \\
\text { Cream }\end{array}$ & $\begin{array}{c}\mathrm{x} \mathrm{W}: 20 \mathrm{~cm} \mathrm{x} \\
10 \mathrm{~cm}\end{array}$ & $\begin{array}{l}\text { Makanan di hidangkan dengan } \\
\text { menggunakan satu piring saja dengan } \\
\text { piring yang berbentuk persegi yang isinya } \\
\text { berupa hidangan corn ice cream. Area } \\
\text { yang digunakan untuk peletakkan piring } \\
\text { tidak besar atau tidak memakan. banyak } \\
\text { tempat sehingga pengunjung bisa } \\
\text { bergerak atau makan dengan nyaman. }\end{array}$ \\
\hline 7. & $\begin{array}{c}\text { Vanilla Ice } \\
\text { Tea }\end{array}$ & D: $6 \mathrm{~cm}$ & $\begin{array}{l}\text { Minuman dihidangkan dengan } \\
\text { menggunakan satu gelas saja berupa } \\
\text { hidangan vanilla ice tea. Area yang } \\
\text { digunakan untuk peletakkan gelas tidak } \\
\text { besar atau tidak memakan. banyak tempat } \\
\text { sehingga pengunjung bisa bergerak atau } \\
\text { makan dengan nyaman. }\end{array}$ \\
\hline 8. & $\begin{array}{l}\text { Welcome } \\
\text { Bread }\end{array}$ & D: $22 \mathrm{~cm}$ & $\begin{array}{l}\text { Makanan di hidangkan dengan } \\
\text { menggunakan satu mangkuk rotan saja } \\
\text { dengan mangkuk rotan yang berbentuk } \\
\text { lingkaran yang isinya berupa hidangan } \\
\text { welcome bread. Area yang digunakan } \\
\text { untuk peletakkan piring tidak besar atau } \\
\text { tidak memakan. banyak tempat sehingga } \\
\text { pengunjung bisa bergerak atau makan }\end{array}$ \\
\hline
\end{tabular}




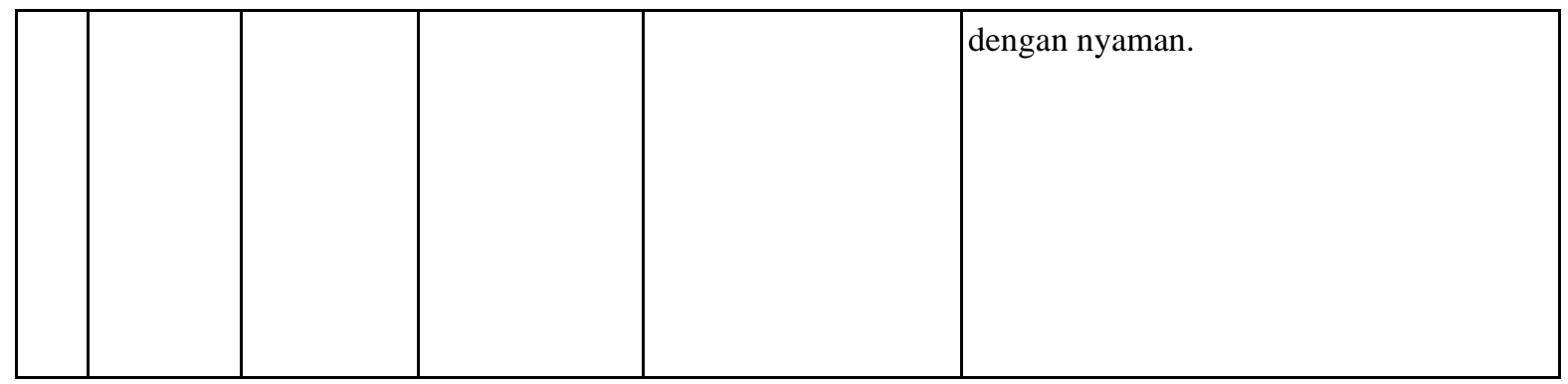

Pada saat peneliti survey mengunjungi restoran tersebut peneliti memesan berbagai macam hidangan a la carte yaitu hidangan 2 main course (lasagna dan chesee burger) , 3 dessert (choco lava ice cream, brownies ice cream, corn ice cream ), 1 appetizer ( soup crab assparagus) , 1 minuman (vanilla ice tea) dan welcome bread. Pada restoran tersebut hidangan yang di sajikan rata-rata adalah hidangan western a la carte atau hidangan untuk satu orang.

- Simulasi dan Ilustrasi Teritori

Agar analisa tersebut lebih jelas lagi maka peneliti menampilkan simulasi atau ilustrasi teritori pada restoran braga permai dengan kursi makan 6 seater dan dengan meja makan berukuran $200 \mathrm{~cm} \times 85 \mathrm{~cm}$.

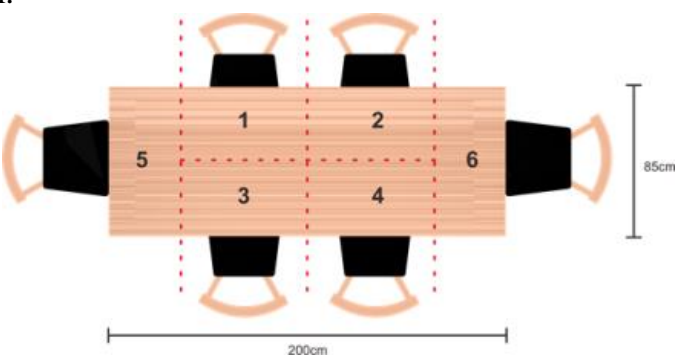

Gambar 7 Ilustrasi Meja Makan Restoran Braga Permai

(Sumber: Wismoyo 2020)

Berikut dimensi skenario penyajian hidangan:

1. Berikut ini adalah table setting pada saat peneliti datang. Terdapat alat makan pada meja tersebut seperti piring, sendok, dan garpu.

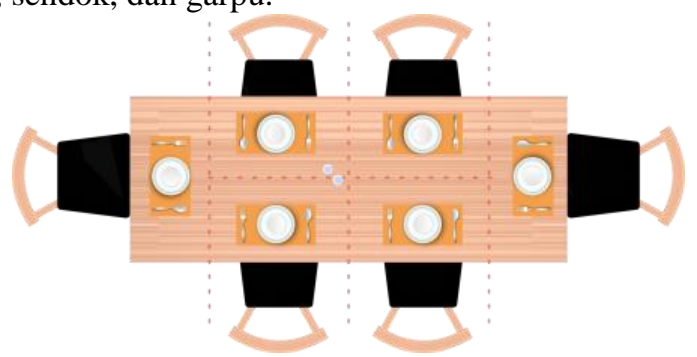

Gambar 8 Ilustrasi Meja Makan Restoran Braga Permai

(Sumber: Wismoyo 2020)

2. Berikut ini adalah table setting pada saat hidangan pertama yaitu welcome bread disajikan. 


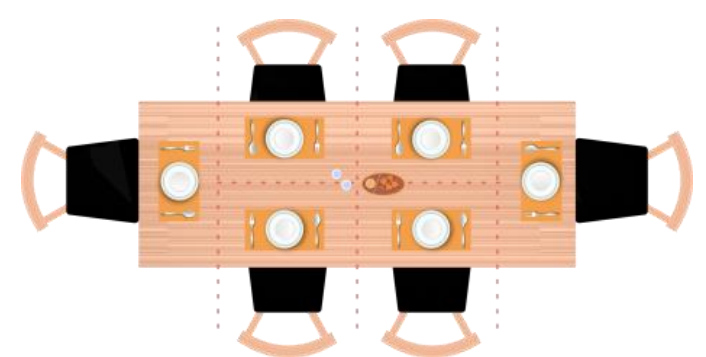

Gambar 9 Ilustrasi Meja Makan Restoran Braga Permai (Sumber: Wismoyo 2020)

3. Menu kedua yang datang adalah menu hidangan dessert, pada saat pelayan mengantar dessert tersebut pelayan tersebut sembari mengambil piring dan alat makan di meja peneliti yang memesan dessert.

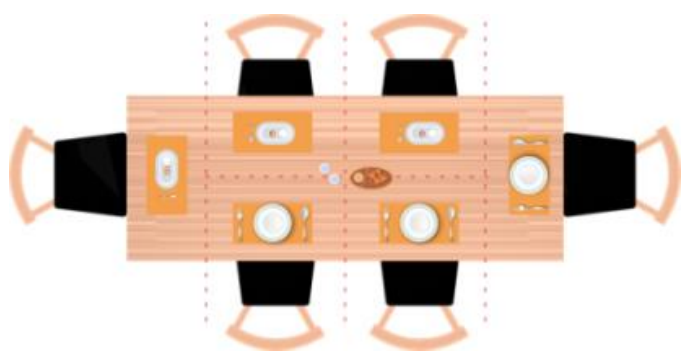

Gambar 10 Ilustrasi Meja Makan Restoran Braga Permai

(Sumber: Wismoyo 2020)

4. Kemudian yang terakhir datang adalah menu hidangan appetizer, main course, dan minuman dengan tambahan satu menu dessert.

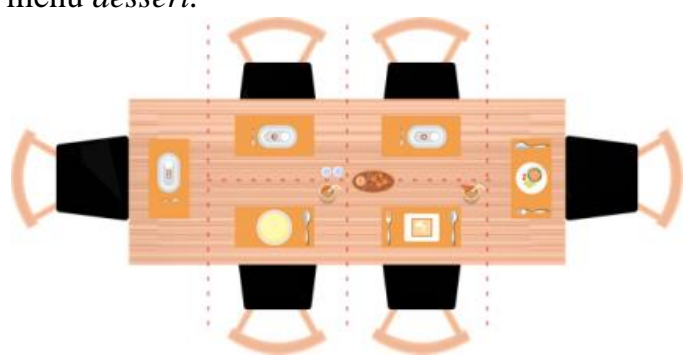

Gambar 11 Ilustrasi Meja Makan Restoran Braga Permai (Sumber: Wismoyo 2020)

Dimensi skenario makan 
Skenario posisi hidangan lebih formal, dengan aksesoris yang di bawa oleh pengunjung berupa sebuah tas jinjing yang diletakkan di atas meja, kaca mata, dan beberapa ponsel.

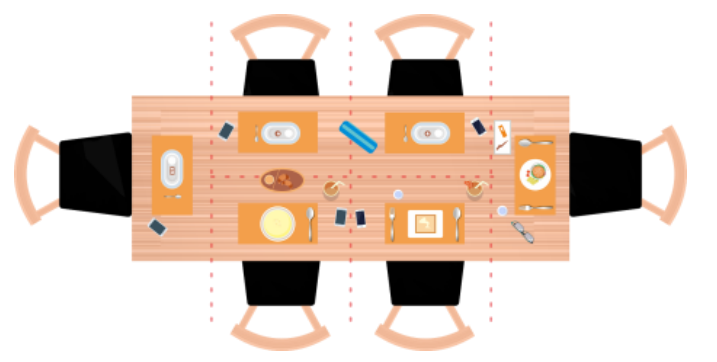

Gambar 12 Ilustrasi Meja Makan Restoran Braga Permai (Sumber: Wismoyo 2020)

Dapat dilihat dari simulasi settingan makan untuk teritori personal berikut ini hidangan di letakan pada masing-masing teritori personal pengunjung atau dengan sistem a la carte:

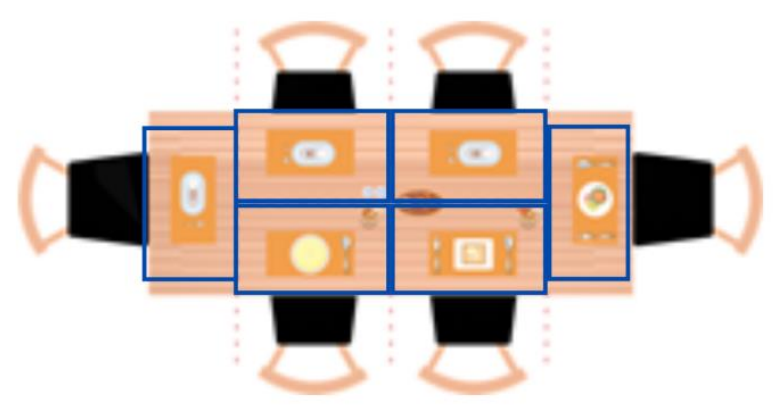

Gambar 13 Ilustrasi Meja Makan Restoran Braga Permai (Sumber: Wismoyo 2020)

- $\quad$ Aktivitas pada Meja Makan Restoran Braga Permai

Ukuran atau dimensi pada restoran braga permai cukup baik dalam memfasilitasi penggunanya yaitu area untuk perlengkapan table setting, nomor meja , tissue , serta bumbu-bumbu (pelengkap makanan) pada setiap meja. Tidak hanya itu pada restoran ini juga terdapat berbagai macam meja makan yang digunakan sesuai dengan jumlah pengunjung yang datang. Menu yang dihidangkan kebanyakan adalah menu khusus untuk 1 orang saja , sehingga dibutuhkan area personal yang cukup. Area personal tersebut memungkinkan pengunjung untuk bergerak dan melakukan aktivitas dengan nyaman.

- Hasil Analisa

Hasil analisa berdasarkan simulasi teritori yang telah dilakukan yaitu penyesuaian simulasi teritori dengan tinjauan standar teritori personal dan dimensi meja makan untuk 6 seater berdasarkan buku human dimension. peneliti mencoba untuk membandingkan analisa dengan standar tersebut untuk menemukan dimensi yang tepat untuk teritori personal. Perbandingan tersebut berupa penguraian tabel.

Tabel 2 Cakupan Meja Makan Restoran Braga Permai 
(Sumber: Wismoyo 2020)

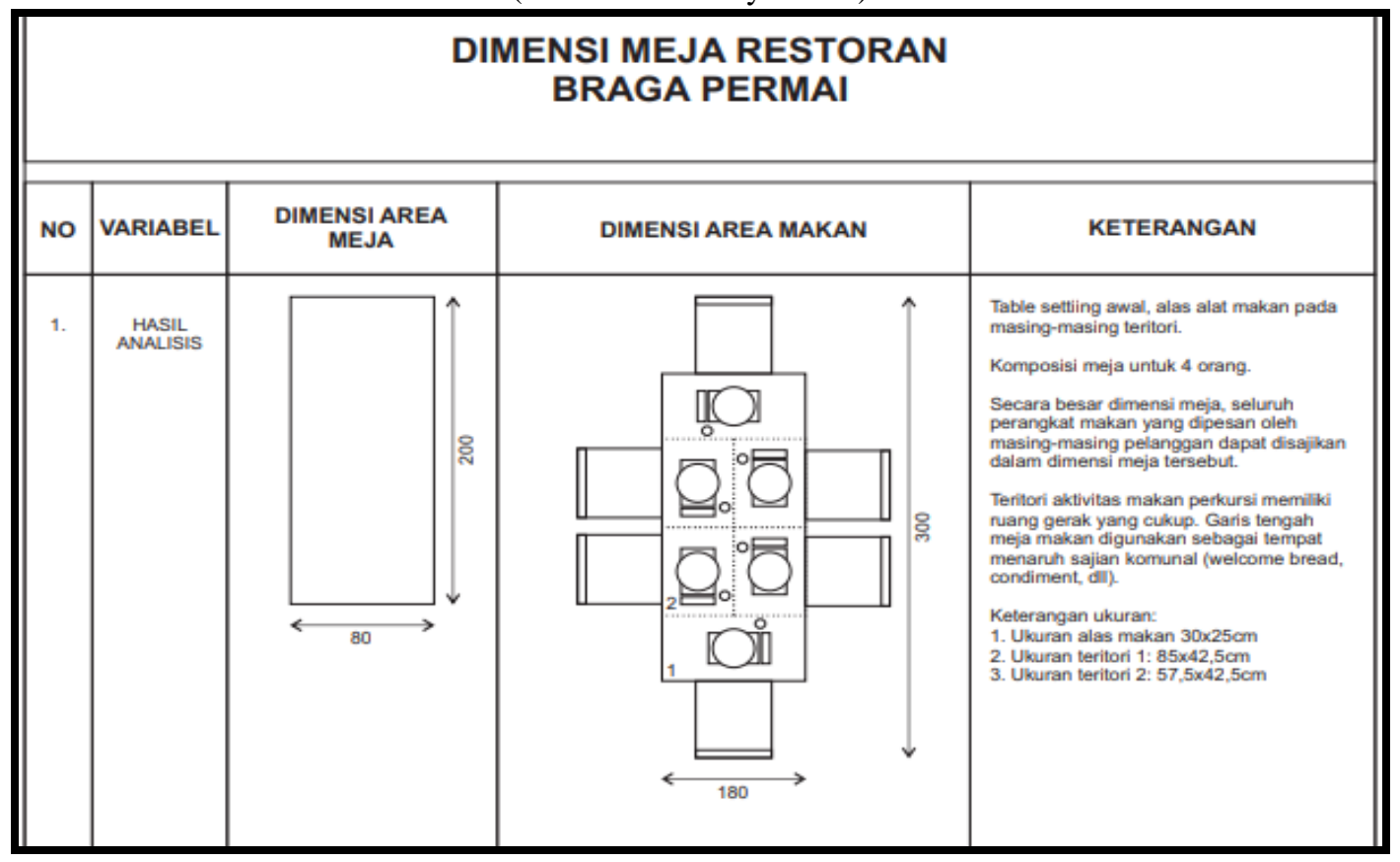

Dari uraian simulasi aktifitas makan minum dan tabel analisa pada restoran Braga Permai dapat di simpulkan bahwa:

1. Pada saat duduk bersebelahan, kebutuhan teritori yang ada pada restoran braga permai sudah cukup terpenuhi namun meja yang digunakan untuk menghidangkan makanan dan untuk pengunjung memiliki sedikit kekurangan pada lebar nya. Meja tersebut agak sedikit lebar sehingga jarak antar pengunjung agak sedikit jauh dengan cakupan dimensi meja secara keseluruhan $200 \times 80 \mathrm{~cm}$.

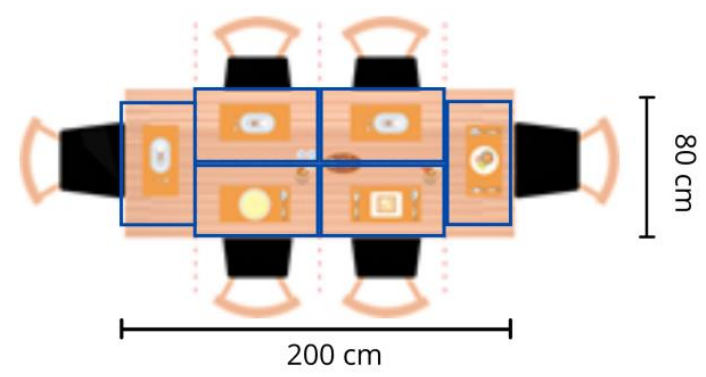

Gambar 14 Ilustrasi Meja Makan Restoran Braga Permai (Sumber: Wismoyo 2020) 
2. Kebutuhan teritori personal 1 pada restoran braga permai adalah dengan cakupan dimensi $57,5 \times 42,5 \mathrm{~cm}$.

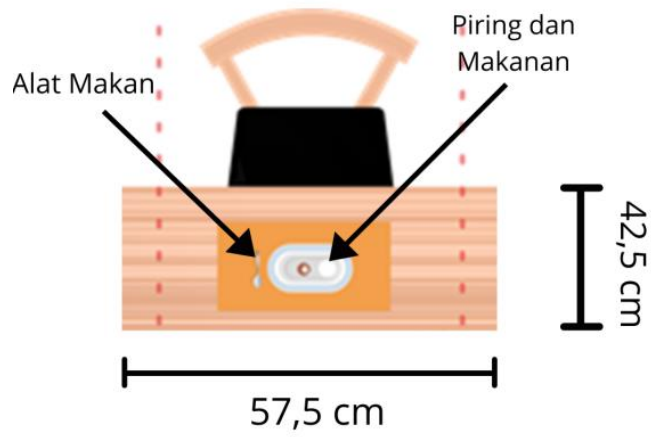

Gambar 15 IlustrasiTeritori Personal Restoran Braga Permai

(Sumber: Wismoyo 2020)

Kebutuhan teritori personal 2 pada restoran braga permai adalah dengan cakupan dimensi $85 \mathrm{x}$ $42,5 \mathrm{~cm}$

3. Secara keseluruhan dimensi meja dan kursi makan yang digunakan dan teritori personal untuk pengunjung sudah cukup baik dan nyaman digunakan pengunjung ketika melakukan aktivitas makan minum dan aktifitas lainnya.

\section{Simpulan}

Kesimpulan dari penelitian ini adalah restoran pada umumnya berfungsi untuk memberikan pelayanan terbaik kepada pengunjungnya berupa hidangan yang lezat dan kenyamanan bagi pengunjung yang datang. Untuk membuat pengunjung merasakan pengalaman terbaik dalam menyantap hidangan tentu saja setiap restoran harus memperhatikan bentuk furniture dan dimensi furniture yang digunakan apakah sudah sesuai dengan standar atau belum. Hal tersebut berkaitan dengan teritori dan ergonomi pada furniture yaitu meja makan dan kursi makan yang digunakan untuk melakukan aktifitas makan dan minum serta aktifitas lainnya.

Teritori personal yang standar menurut buku human dimension ketika makan bersama untuk 6 seater adalah 80-121,9 cm sedangkan teritori personal yang standar menurut buku Human Dimension ketika makan bersama untuk 4 seater adalah 60-76 cm dan menurut buku Data Architect adalah sekitar $60 \mathrm{~cm}$, teritori atau area dengan ukuran tersebut tidak mutlak tepat untuk aktivitas pengguna meja makan. Dalam simulasi ini peneliti mendapatkan penyesuaian yang tidak dimiliki oleh sumber-sumber literatur diatas. Memasukkan variabel teritori personal, dan konteks jenis restoran bertujuan untuk mendapatkan angka dimensi yang tepat dan sesuai dengan konteks ruangnya.

Setelah melakukan penelitian terkait teritori personal pada restoran Braga Permai dan pembahasan terkait teritori personal yang digunakan untuk hidangan a la carte, maka dapat diketahui bahwa pada restoran Braga Permai dimensi teritori personal dapat terpenuhi dengan cakupan dimensi 57,5 x 42,5cm, dengan begitu teritori personal ketika melakukan aktifitas makan minum maupun aktifitas lainnya dapat terpenuhi. Berdasarkan penelitian tersebut kesimpulan yang di dapat bahwa teritori personal setiap restoran tentu saja memiliki perbedaan, hal tersebut tergantung dari bentuk furniture dan peralatan makan yang digunakan. Setiap restoran perlu memperhatikan konteks ruang berdasarkan jenis restoran, dan dimensi furniture atau meja makan yang akan digunakan oleh pengunjung agar teritori personal tersebut dapat memfasilitasi pengunjung dan pengunjung dapat melakukan aktifitas makan dan minum serta aktifitas lainnya dengan baik 


\section{Daftar Pustaka}

Hanom, I. (2017). Interaksi Manusia Dengan Multi Modal Text Study Kasus: Meja Makan Di Restoran Sushi Groove, Paris Van Java Bandung. Jurnal IDEALOG, 297-309.

Karjodihardjo, Y. H., \& Honggowidjaja, S. P. (2015). Perancangan Interior Library Cafe di Surabaya. JURNAL INTRA, 256-267.

Ling, L. L. (2016). Perancangan Interior Restoran Museum Surabaya. JURNAL INTRA, 554-563.

Mattila, A. S. (2015). An Examination Of Factors Affecting Service Recovery In A Restaurant Setting. Journal of Hospitality \& Tourism Research, 284-298.

Neufert , E. (2002). Data Arsitek Jilid 2. Jakarta: Erlangga.

Nur'aini, R. D., \& Ikaputra. (2019). Teritorialitas Dalam Tinjauan Ilmu Arsitektur. INERSIA, 12-22.

Oscar, A. (2009, Juni 26). Diambil kembali dari Mengenal Perancis Lebih Jauh Lewat Seni Kulinernya: http: //www.epochtimes.co.id

Panero, J., \& Martin, Z. (1980). Human Dimension \& Interior Space. London: The Architectural Press Ltd.

Pratama, D., Lintu, T., \& Hendy, M. (2019). Perancangan Interior Restoran \& Kafe Dengan Konsep Kontemporer Tradisional Khas Lombok di Lombok. JURNAL INTRA, 781-792.

Puspoyo, A. C., Setiawan, A. P., \& Wondo, D. (2015). Perancangan Interior Kafe Dan Resto The Historic Of Blitar. Jurnal INTRA, 80-91.

Tuzunkan, D., \& Albayrak, A. (2016). The Importance of Restaurant Physical Environment For Turkish Customers. SCITECHNOL JOURNAL, 1-7.

https://www.academia.edu/36657951/Rangkuman_Materi_Tata_Hidang. Diakses pada tanggal 14 Agustus 2020.

https://www.dosenpendidikan.co.id/jenis-jenis-restoran/. Diakses pada tanggal 29 Juli 2020. 